\title{
COMMENTARY
}

\section{Nordic National Climate Adaptation and Tourism Strategies - (How) Are They Interlinked?}

\author{
Mia Landauer ${ }^{1}$, Michael Evan Goodsite ${ }^{2,5}$, and Sirkku Juhola ${ }^{3,4}$ \\ ${ }^{1}$ Risk and Resilience Program \& Arctic Futures Initiative, International Institute for \\ Applied Systems Analysis (IIASA), Austria \\ 2 The Faculty of Engineering, University of Southern Denmark, Denmark \\ ${ }^{3}$ Department of Environmental Sciences, University of Helsinki, Finland \\ ${ }^{4}$ Department of Built Environment, Aalto University, Finland \\ ${ }^{5}$ Environment and Natural Resources, University of Iceland, Iceland
}

Corresponding author:

Mia Landauer, Risk and Resilience Program \& Arctic Futures Initiative

International Institute for Applied Systems Analysis (IIASA), Schlossplatz 1, A-2381

Laxenburg, Austria

\section{Email: landauem@iiasa.ac.at}

ABSTRACT The tourism sector is affected by climate change worldwide. Nordic tourism destinations offering various activities for tourists have also experienced changes, such as changing precipitation patterns, lack of snow in winter, and shifts in seasons. The tourism sector has to implement adaptation strategies but it is unclear whether the current public climate policy is sufficient to support considering adaptation actions. We reviewed national climate strategies of the Nordic countries from the perspectives of tourism, but excluding the transport sector. We also reviewed Nordic national tourism strategies from the perspective of climate change, particularly the extent to which they address climate adaptation concerns. We found out that the national climate strategies do not pay enough attention to tourism adaptation needs, nor do the national tourism strategies present adaptation actions that tourism actors could consider to implement. To connect these national level strategies, there is a need to review currently available and potential adaptation actions for tourism within the national adaptation framework supported by research based evidence. Next, by means of Nordic cooperation, guidance for both public and private tourism actors within and across Nordic countries can be provided. This can particularly enhance the competitiveness and resilience of the Nordic tourism supply and contribute to the development of economically, environmentally and socially sustainable tourism in the region.

KEY WORDS: Nordic countries, tourism management, public policy, climate change, national adaptation strategies 


\section{Background}

Changes in temperature, precipitation, and particularly the occurrence of extreme weather events affect tourism destinations, and climate change will continue to impact tourism destinations and tourists themselves (Amelung \& Nicholls, 2014; Dawson \& Scott, 2013; IPCC, 2012; Jopp, DeLacy, \& Mair, 2010; Kajan \& Saarinen, 2013; Perch-Nielsen, 2010; Saarinen, 2014; Scott, Hall, \& Gössling, 2012; Scott \& Lemieux, 2010).

According to Becken (2013), research interest in tourism and climate change has grown rapidly between 1986 and 2012. Research on multiple dimensions such as impacts, adaptation, mitigation, and policy analyses has evolved, and now tourism and climate change can be considered their own knowledge domain. However, the role of tourism players, especially private actors in national climate policy-making has been rather passive, and there is a need for tourism-specific climate policy, including actors from interdependent policy networks and both state and non-state sectors to better address this highly complex problem of climate change (Becken \& Clapcott, 2011) across scales.

The OECD/United Nations Environment Programme (2011) report states that national policies require tourism-specific assessments to determine the consequences of climate change, both from adaptation and mitigation perspectives. Although the report does not specifically focus on Nordic countries, we argue that it provides an important starting point for this kind of discussion in the Nordic countries. Identification of national-level progress on climate adaptation (see Lesnikowski, Ford, Biesbroek, Berrang-Ford, \& Heymann, 2016) would be useful to stay updated on the status of adaptation of (Nordic) tourism, as well. Adger (2001) points out that public policy can play an important role in climate adaptation policy-making and implementation. According to several studies (e.g. Biesbroek \& Swart, 2014; Siegrist \& Gessner, 2011), public intervention is needed to 
complement and support adaptation activities taken by private tourism businesses. It is also needed because climate change related collaboration between tourism actors has not always received particular interest among tourism entrepreneurs (e.g. Saarinen \& Tervo, 2006; Tervo-Kankare, 2011). For instance, the realization of cooperation possibilities has been considered difficult due to the competition (Scott, de Freitas \& Matzarakis, 2009). National level public coordination and interaction with private actors could help to increase cooperation between tourism actors within and between Nordic countries to share knowledge and resources, as well as raise awareness of climate change and adaptation possibilities of tourism.

\section{Approach}

In this commentary, we review the Nordic national tourism strategies with regards to climate change and how climate adaptation of the tourism sector in Nordic countries' national climate adaptation strategies and other climate policy documents is recognized. If national level planning of adaptation strategies and tourism strategies are disconnected, we consider it difficult to assess the consequences of climate change on tourism in a holistic manner such as destinations' quality and services offer and plan adaptation strategies across different scales. National level adaptation strategies could provide useful insights into tourism destinations' adaptation planning and management, if conducted in a collaborative manner with different kinds of tourism actors (public and private stakeholders) to be able to co-generate and share knowledge on potential benefits of changing climate in the Nordic countries. This commentary aims to find linkages between the national adaptation strategies and national tourism strategies. However, it should be noted that the transport sector is out of the scope of this commentary. 
Our first question is: in what ways, if at all, do the national climate strategies consider climate adaptation of the tourism sector, or climate change of the sector on a more general level? Therefore, we examine whether and how the current national climate policies in the Nordic countries take into account, and ideally, contribute to providing guidance for climate change adaptation in tourism destinations. Next, we assess the extent to which climate change is a concern in the Nordic tourism sector by reviewing national tourism strategies. This relates to our second question: to what extent, if at all, is climate change and adaptation concerns integrated into the Nordic tourism strategies to support tourism sector, for example destinations that offer nature-based tourism activities but are affected by climate change and extreme weather events?

\section{Data and Methods}

First, we reviewed scientific papers and reports, as well as the webpages of Nordic adaptation related research programmes and projects to provide an overview of the relevance of tourism and the influence of climate change on Nordic tourism sector. Next, we reviewed government climate policy documents from countries where official national adaptation strategies are not yet available, and of official national adaptation strategies in countries where they are already available, as well as a selection of national level tourism strategies in the Nordic countries. The national policy documents were published between 2000 and 2014 (details in Table 1). We examined whether (if at all) and in which contexts the keywords "hospitality”, "tourism” or "tourist” appear in the climate policy documents, and whether (if at all) and which contexts the keywords “adaptation” or "adapt” and "climate" or "climate change" were mentioned in the tourism strategies. We used the same keywords for the documents only available in the original but translated accordingly. After this procedure, we made an in-depth analysis of the content of the policy documents. 


\section{Tourism in the Nordic countries}

Tourism $^{1}$ is important for the local economic and social development of the Nordic countries (Genc, 2010; Hall, Müller, \& Saarinen, 2009; Nicholls \& Amelung, 2015). When considering the total (direct and indirect) contribution of the travel and tourism economy to the national gross domestic product in 2012, tourism contributed approximately $7 \%$ to the national GDP in Denmark, Finland and Norway, as well as $19.5 \%$ in Iceland and $10.8 \%$ in Sweden. The differences can be explained by the larger proportion of employment in tourism in the latter two countries (see Nicholls \& Amelung, 2015). Overall, nature-based and rural tourism characterise (but not necessarily dominate) the Nordic tourism sector, in addition to cruise ship tourism, sailing and coastal tourism, as well as health and wellness tourism, and cultural tourism both in urban and rural settings (e.g. European Commission, 2015; Haukeland,Therkelsen, Furunes, \& Mykletun, 2010) - business, congress and work related travel as well as transport sector as a part of the revenue but being out of the context of this commentary.

\section{Climate Change Concerns and Adaptation Challenges}

Weather variability and unexpected climatic conditions cause financial losses in particular for nature-based tourism operators because they hinder tourism activities at the destinations, reduce the attractiveness of tourism areas, and thus, lead to a decline in tourism flows (Amelung, Nicholls, \& Viner, 2007; Haanpää, Juhola, \& Landauer, 2015; Lundmark, 2010; Scott et al., 2012; Tervo, 2008). This in turn affects the welfare of socioeconomic locales dependent on tourism. Because temperatures are expected to increase at

\footnotetext{
${ }^{1}$ With 'tourism' we mainly mean the rather popular definition 'voluntary holiday travel for pleasure and leisure', which covers 'domestic', 'inbound' and 'outbound tourism' (see Hall \& Lew, 2009, pp. 5-13). Quoting Lundmark and Müller (2010, p. 381), “[n]ature-based tourism in its widest sense incorporates all tourism that takes place in areas rich in natural amenities as well as activities connected to nature...”
} 
northern latitudes and extreme weather events are taking place (see Arent, Tol, Faust, Hella, Kumar, Strzepek, Tóth, \& Yan, 2014; IPCC, 2012; Makkonen, Ruokolainen, Räisänen, \& Tikanmäki, 2007; Räisänen \& Eklund, 2012), also Nordic tourism destinations need actions that substitute tourism activities that are no longer possible due to climate change, and/or that compensate the range of activities currently provided. Examples of adaptation actions listed in the literature include provision of alternative activities, such as Nordic Walking and hiking instead of skiing, or indoor wellness activities during rainy summers instead of beach activities, and technical options such as artificial snow-making, just to mention a few.

Many tourism studies conclude that there will be winners and losers in tourism sector due to climate change (see Pröbstl-Haider, Haider, Wirth \& Beardmore, 2015 for a detailed review). Therefore, the tourism sector needs development and refinement of the offer (adaptation of service infrastructure and activities, and re-orientation of the offer), but this has to match with the demand, taking into account the very heterogeneous preferences of tourists (Gössling \& Hall, 2006; Denstadli, Jacobsen, \& Lohmann, 2011; Gössling, Scott, Hall, Ceron, \& Dubois, 2012; Førland, Jakobsen, Denstadli, Lohmann, Hanssen-Bauer, Hygen, \& Tømmervik, 2013; Landauer, Haider, \& Pröbstl-Haider, 2013; Pröbstl-Haider et al., 2015). The UNWTO Tourism Highlights (UNWTO, 2015) shows an increase in international tourist arrivals in two Nordic countries. In Iceland, the change in 2014 compared to 2013 is $23.6 \%$, and in Norway $1.6 \%$, based on this one variable. This provides a positive sign for the Nordic tourism sector, despite the fact that some climate change impacts are already visible. However, information on, for example, potential intranational and intra-generational changes and trends in destination choice preferences and behaviour of tourists due to climate change would be useful. There is a need to understand 
the complex interactions between multiple variables and find factors that can positively affect the Nordic tourism sector also in a longer term. Ideally, climate adaptation strategies can enhance transformation of climate change challenges into opportunities and support adaptation actions that increase economic, environmental and social sustainability of tourism development proactively.

\section{Are There Linkages between National Climate Strategies and Tourism Strategies?}

In the last fifteen years, tourism researchers have become particularly interested in climate adaptation, as the comprehensive reviews of Kaján \& Saarinen (2013) and the introduction to the special issue on Nordic perspectives in Scandinavian Journal of Hospitality and Tourism show (Saarinen, 2014). However, few studies examine the role of national level public policy making from the perspective of tourism in the context of climate change. This is even though the Nordic countries have addressed the need for adaptation strategies for the sector in many research programmes and other adaptation related projects.

Just to mention a few, the research projects FINADAPT (www.syke.fi/hankkeet/finadapt) and MAVERIC (www.syke.fi/projects/maveric) have considered the adaptation of tourism in Finland, as well as Clim-ATIC, a collaborative project in Finland, Greenland, Norway, Sweden and Scotland (www.clim-atic.org/). In Norway, the government research initiative NORDSATSING has focused on tourism adaptation (The Research Council of Norway, 2012). In Denmark, the Task Force on Climate Change Adaptation (Danish Nature Agency, 2012) has also considered tourism, among other sectors, although the Danish adaptation strategy (The Danish Government, 2008) does not mention the adaptation of tourism.

Our policy document review shows that tourism has been briefly mentioned in the national adaptation strategies or national strategies under preparation in the Nordic countries in 
Sweden, Norway and Finland. Each country’s individual Fifth National Communication under the United Nations Framework Convention on Climate Change report addresses tourism, except the Icelandic one. Therefore, it is somewhat surprising that climate change has not gained broader tourism specific attention in the strategies, or led to concrete actions, in the form of specific recommendations or guidelines, or concrete evaluations or assessments, for example. The exceptions are Finland, where potential measures and some implemented measures have been mentioned in the national adaptation strategy (see Marttila, Granholm, Laanikari, et al., 2005; Ministry of Agriculture and Forestry, 2014), and Sweden, where some measures are mentioned in the Swedish Commission on Climate and Vulnerability (2007) report. Furthermore, the review of tourism strategies shows that adaptation has received no attention at all, although general concerns about climate change can be found. The national tourism strategies (except the Danish ones) mention climate change a few times, but climate adaptation is not mentioned in them (Table 1).

<Insert: Table 1. National climate and tourism policy documents.>

\section{Discussion}

\section{Role of Public Policies}

This commentary highlights the need for public policy (national adaptation strategies) to support Nordic tourism development under a changing climate. Our review of national policy documents reveals gaps in the national strategies regarding climate adaptation of tourism. We suggest that the planning and implementation of climate change adaptation actions for tourism should be a part of the national adaptation strategies because of the economic importance of the sector nationally, as well as regionally. We also think that tourism strategies should include climate change adaptation as a core part of tourism management and destination development concerns, as this can improve sustainable climate adaptation and related transformation of the sector in the long term. 
Many studies (see Pröbstl-Haider et al., 2015) have discussed new opportunities brought about by climate change. In reality, the diversification or relocation of activities of the tourism destinations depends on available resources, tourists' demand for such activities and geographical location too, but very often also tourism operators' willingness to realise such actions (e.g. Haanpää et al. 2015). The missing linkage between national climate strategies and tourism strategies does not provide a good model for tourism operators. It does not motivate to take adaptation action, especially among those operators who are still sceptical of climate change (Trawöger, 2014) or those who do not see collaboration with the public sector worthwhile (Saarinen \& Tervo, 2006).

We argue that national adaptation strategies can play an important role in providing information and guidance for tourism adaptation planning and management. Even though the special features of each country and destination must be taken into consideration when developing adaptation actions for tourism destinations, national public adaptation policy can set the framework for adaptation of tourism. In particular, it can support the creation of long-term plans in a sector that tends to rely more on short-term goals (Haanpää, et al., 2015; Trawöger, 2014).

\section{Role of Research}

The role of research in assessing the capacity and demand for adaptation can provide necessary information for policy makers and tourism businesses to develop adaptation strategies. It is sometimes challenging to make accurate local level or site level predictions on the potential impacts and resulting consequences of climate change. For instance, global climate scenarios alone are seldom suitable for this purpose, due to challenges of 
downscaling global scenarios to local or regional circumstances (Dubois \& Ceron, 2006). However, Biesbroek and Swart (2014) argue that more research is needed on the climate related risks, vulnerability, and uncertainty in particular, as well as the costs and benefits of adaptation. Research has already covered many climate related threats to Nordic tourism sector on a country level (see Saarinen, 2014), but also a Nordic-wide assessment of climate vulnerability and risks would be needed. Furthermore, survey-based empirical data on preferences from both destination management and from tourists themselves can provide important insights for tourism management (see Konu, Laukkanen, \& Komppula, 2011; Landauer, Pröbstl, \& Haider, 2012; Tervo-Kankare, 2011). Research can provide evidence-based advice for decision-making and elaborations on whether and how public intervention is needed to evaluate needs for climate adaptation (Biesbroek \& Swart, 2014).

Although the Nordic region is not the main tourism market area globally, it is an important international market niche in adventure and nature-based tourism sectors in particular, and an important hub also for city tourism. The role of Nordic tourism regions may even increase if the climate becomes warmer and the current tourism "hot spot” regions, such as the Mediterranean, start to lose their appeal due to heat waves and droughts, for instance (Arent et al., 2014; IPCC, 2012). Given that the identification of future demand of tourists, especially the varying preferences of tourist segments, is challenging, we consider it crucial to get public policy and research support for tourism destinations to plan and implement adaptation strategies and identify opportunities for the Nordic tourism sector. So far no systematic analysis on this has been conducted in the Nordic countries. 
In the face of climate change, adaptation strategies and cooperation across different policy levels can help balance the economic, social and environmental development that Nordic tourism provides. To be able to succeed among the many competing offers, the Nordic tourism operators need new innovations, product and service orientation, communication, sector development and better interaction between cross-border, cross-sector, public and private stakeholders (see Nordic Innovation Centre, 2008). Adaptation capacity can be enhanced by collaborative planning and implementation of national adaptation strategies together with tourism stakeholders, e.g., by means of creating networks of national, subnational, and local tourism actors and adaptation policy makers (see Halkier, 2010). Also Biesbroek and Swart (2014) found that although some national policies in Europe mention tasks for adaptation of tourism sector, adaptation has been often considered rather a private responsibility of tourism businesses: it has been unclear how to coordinate adaptation actions. Therefore a sustained and inclusive dialogue between public and private actors across scales is also needed.

EU policies and programmes are considered advantageous to further help exchange experiences and improve coordination of competition policy and regional development in order to identify their strategic implications for tourism development in the Nordic countries (see Halkier, 2010; Nordic Innovation Centre, 2008). These kinds of “joint Nordic forces” in tourism development would be important to enhance Nordic competiveness also in the international tourism market.

\section{Conclusion}

This commentary points out that the national climate strategies of the Nordic countries do not pay sufficiently attention to the need for adaptation of the tourism sector, nor do the national level tourism strategies present adaptation actions that actors in the tourism sector 
could consider or best practices of already implemented ones. Thus, there is a need for reciprocity and mutual interaction between the actors responsible for national adaptation policies, as well as those responsible for implementing tourism strategies. This is required to provide adaptation knowledge for tourism destinations and to consider adaptation actions for tourism sector in the national adaptation strategies.

Climate information and knowledge about adaptation are needed to prepare for climate change in the Nordic tourism sector to face the challenges and enhance opportunities that climate change will bring about. The national adaptation policies can provide direction for developing and implementing adaptation strategies because of information they contain on country-specific circumstances (social, economic, environmental and political) on different business sectors. Participatory processes, including research, policy and business stakeholders across multiple institutional, spatial, organizational and management scales are required to increase knowledge on best practices and interactions between climate adaptation policy-making and tourism development and planning.

\section{Acknowledgements}

The preparation of this publication has been supported by the Norden Top-level Research Initiative sub-programme 'Effect Studies and Adaptation to Climate Change' through the Nordic Centre of Excellence for Strategic Adaptation Research (NORD-STAR). 


\section{References}

Adger, W.N. (2001). Scales of governance and environmental justice for adaptation and mitigation of climate change. Journal of International Development, 13(7), 921931.

Amelung, B., Nicholls, S., \& Viner, D. (2007). Implications of global climate change for tourism flows and seasonality. Journal of Travel Research, 45(3), 285-296.

Amelung, B., \& Nicholls, S. (2014). Implications of climate change for tourism in Australia. Tourism Management, 41, 228-244.

Arent, D.J., Tol, R.S.J., Faust, E., Hella, J.P., Kumar, S., Strzepek, K.M., Tóth, F.L., \& D. Yan, D. (2014). Key economic sectors and services. In: Field, C.B., V.R. Barros, D.J. Dokken, K.J. Mach, M.D. Mastrandrea, T.E. Bilir, M. Chatterjee, K.L. Ebi, Y.O. Estrada, R.C. Genova, B. Girma, E.S. Kissel, A.N. Levy, S. MacCracken, P.R. Mastrandrea, and L.L. White (eds.). Climate Change 2014: Impacts, Adaptation, and Vulnerability. Part A: Global and Sectoral Aspects. Contribution of Working Group II to the Fifth Assessment Report of the Intergovernmental Panel on Climate Change. Cambridge University Press, Cambridge, United Kingdom and New York, NY, USA, 659-708.

Becken, S., \& Clapcott, R. (2011). National tourism policy for climate change. Journal of Policy Research in Tourism, Leisure \& Events, 3(1), 1-17.

Becken, S. (2013). A review of tourism and climate change as an evolving knowledge domain. Tourism Management Perspectives, 6, 53-62.

Biesbroek, R., \& Swart, R.J. (2014). National adaptation policy processes in European countries-2014 (No. 4, p. 136). European Environment Agency.

Danish Nature Agency. (2012). Mapping climate change - barriers and opportunities for action. Background report. Task Force on Climate Change Adaptation. Retrieved 
from: http://naturstyrelsen.dk/publikationer/2013/mar/mapping-climate-change/ (6 June, 2017)

Dawson, J., \& Scott, D. (2013). Managing for climate change in the alpine ski sector. Tourism Management, 35, 244-254.

Denstadli, J. M., Jacobsen, J. K. S., \& Lohmann, M. (2011). Tourist perceptions of summer weather in Scandinavia. Annals of Tourism Research, 38(3), 920-940.

Dubois, G., \& Ceron, J.P. (2006). Tourism and climate change: Proposals for a research agenda. Journal of Sustainable Tourism, 14(4), 399-415.

European Commission (2015). Tourism industry subsectors of European countries. Retrieved from http://ec.europa.eu/growth/tools-databases/tourism-businessportal/business/internationalization/subsectors/index_en.htm (6 June, 2017).

Førland, E. J., Jacobsen, J. K. S., Denstadli, J. M., Lohmann, M., Hanssen-Bauer, I., Hygen, H. O., \& Tømmervik, H. (2013). Cool weather tourism under global warming: Comparing Arctic summer tourists' weather preferences with regional climate statistics and projections. Tourism Management, 36, 567-579.

Genc, R. (2010). Turning weaknesses into strengths: Nordic tourism, potentials for growth and major challenges. Acta Universitatis Danubius. Economica, 6(1).

Gössling, S., \& Hall, C. M. (2006). Uncertainties in predicting tourist flows under scenarios of climate change. Climatic Change, 79(3-4), 163-173.

Gössling, S., Scott, D., Hall, C. M., Ceron, J. P., \& Dubois, G. (2012). Consumer behaviour and demand response of tourists to climate change. Annals of Tourism Research, 39(1), 36-58.

Haanpää, S., Juhola, S., \& Landauer, M. (2015). Adapting to climate change: perceptions of vulnerability of down-hill ski area operators in Southern and Middle Finland. Current Issues in Tourism, 18(10), 966-978. 
Halkier, H. (2010). EU policy and Nordic tourism development. Scandinavian Journal of Hospitality and Tourism, 10(2), 89-91.

Hall, C.M., Müller, D.K., \& Saarinen, J. (2009). Nordic tourism - Issues and cases. 310 p.

Hall, C. M., \& Lew, A.A. (2009). Understanding and managing tourism impacts: An integrated approach. Routledge.

Haukeland, J.V., Therkelsen, A., Furunes, T., \& Mykletun, R.J. (2010). 10-year anniversary editorial. Scandinavian Journal of Hospitality and Tourism, 10(3), 173-176.

IPCC (2012). Managing the Risks of Extreme Events and Disasters to Advance Climate Change Adaptation. In Field, C.B., V. Barros, T.F. Stocker, D. Qin, D.J. Dokken, K.L. Ebi, M.D. Mastrandrea, K.J. Mach, G.-K. Plattner, S.K. Allen, M. Tignor, and P.M. Midgley (Eds.). A Special Report of Working Groups I and II of the Intergovernmental Panel on Climate Change. Cambridge University Press, Cambridge, UK, and New York, NY, USA, 582 p.

Jopp, R., DeLacy, T., \& Mair, J. (2010). Developing a framework for regional destination adaptation to climate change. Current Issues in Tourism, 13(6), 591-605.

Kaján, E., \& Saarinen, J. (2013). Tourism, climate change and adaptation: A review. Current Issues in Tourism, 16(2), 167-195.

Konu, H., Laukkanen, T., \& Komppula, R. (2011). Using ski destination choice criteria to segment Finnish ski resort customers. Tourism Management, 32(5), 1096-1105.

Landauer, M., Pröbstl, U., \& Haider, W. (2012). Managing cross-country skiing destinations under the conditions of climate change-scenarios for destinations in Austria and Finland. Tourism Management, 33(4), 741-751. 
Landauer, M., Haider, W., \& Pröbstl-Haider, U. (2013). The influence of culture on climate change adaptation strategies: preferences of cross-country skiers in Austria and Finland. Journal of Travel Research, 53(1), 96-110.

Lesnikowski, A., Ford, J., Biesbroek, R., Berrang-Ford, L., \& Heymann, S. J. (2016). National-level progress on adaptation. Nature Climate Change, 6(3), 261-264.

Lundmark, L. (2010). A holiday on ice on hold? Nature-based tourism and climate change in the Nordic north. In: Hall, M.C., \& Saarinen, J. (eds.): Tourism and change in Polar Regions: climate, environment and experience. Routledge, London, 135-146.

Lundmark, L., \& Müller, D.K. (2010). The supply of nature-based tourism activities in Sweden. Turizam: znanstveno-stručni časopis, 58(4), 379-393.

Makkonen, L., Ruokolainen, L., Räisänen, J., \& Tikanmäki, M. (2007). Regional climate model estimates for changes in Nordic extreme events. Geophysica, 43(1-2), 19-42.

Marttila, V., Granholm, H., Laanikari, J., Yrjölä, T., Aalto, A., Heikinheimo, P., ... \& Paunio, M. (2005). Finland's national strategy for adaptation to climate change. Publications of the Ministry of Agriculture and Forestry 1a/2005. Retrieved from http://www.mmm.fi/en/index/frontpage/climate_change_energy/adaption.html (10 April, 2017).

Ministry of Agriculture and Forestry (2014). Finland's National Climate Change Adaptation Plan 2022. Retrieved from http://www.mmm.fi/en/index/frontpage/climate_change_energy/adaption.html (6 June, 2017).

Nicholls, S., \& Amelung, B. (2015). Implications of climate change for rural tourism in the Nordic region. Scandinavian Journal of Hospitality and Tourism, 15(1-2), 48-72.

Nordic Innovation Centre. (2008). Nordic innovation in the tourism sector. Paper with recommendations from workshop in Copenhagen, June 2008. 
OECD/United Nations Environment Programme. (2011). Climate Change and Tourism Policy in OECD Countries. OECD Studies on Tourism. OECD Publishing. Retrieved from: http://dx.doi.org/10.1787/9789264119598-en (6 June, 2017)

Perch-Nielsen, S. L. (2010). The vulnerability of beach tourism to climate change—an index approach. Climatic Change, 100(3-4), 579-606.

Pröbstl-Haider, U., Haider, W., Wirth, V., \& Beardmore, B. (2015). Will climate change increase the attractiveness of summer destinations in the European Alps? A survey of German tourists. Journal of Outdoor Recreation and Tourism, 11, 44-57.

Räisänen, J., \& Eklund, J. (2012). 21st Century changes in snow climate in Northern Europe: a high-resolution view from ENSEMBLES regional climate models. Climate Dynamics, 38(11-12), 2575-2591.

Saarinen, J. \& Tervo, K. (2006) Perceptions and adaptation strategies of the tourism industry to climate change: the case of Finnish nature-based tourism entrepreneurs. International Journal of Innovation and Sustainable Development, 1(3), pp. 21428.

Saarinen, J. (2014). Nordic perspectives on tourism and climate change issues. Scandinavian Journal of Hospitality and Tourism, 14(1), 1-5.

Scott, D., \& Lemieux, C. (2010). Weather and climate information for tourism. Procedia Environmental Sciences 1, 146-183

Scott, D., Hall, C.M., \& Gössling, M. (2012): Tourism and climate change. Impacts, adaptation and mitigation. London: Routledge.

Scott, D., de Freitas, C., \& Matzarakis, A. (2009). Adaptation in the tourism and recreation sector. In Biometeorology for adaptation to climate variability and change (pp. 171-194). Springer Netherlands. 
Siegrist, D., \& Gessner, S. (2011). Klimawandel: Anpassungsstrategien im Alpentourismus. Ergebnisse einer alpenweiten Delphi-Befragung. TW Zeitschrift für Tourismuswissenschaft, 3(2), 179-194.

Swedish Commission on Climate and Vulnerability (2007). Sweden facing climate change - threats and opportunities. Swedish Government Official Reports (SOU 2007:60).

Tervo, K. (2008). The operational and regional vulnerability of winter tourism to climate variability and change: the case of the Finnish nature-based tourism entrepreneurs. Scandinavian Journal of Hospitality and Tourism, 8(4), 317-332.

Tervo-Kankare, K. (2011). The consideration of climate change at the tourism destination level in Finland: Coordinated collaboration or talk about weather? Tourism Planning \& Development, 8(4), 399-414.

The Danish Government. (2008). Danish Strategy for Adaptation to a Changing Climate. Retrieved from http://en.klimatilpasning.dk/media/5322/klimatilpasningsstrategi_uk_web.pdf (6 June, 2017)

The Research Council of Norway. (2012). Norwegian climate research. An evaluation. Division for Energy, Resources and the Environment. Retrieved from: http://www.forskningsradet.no/en/Article/Evaluation_of_Norwegian_climate_resea rch/1253966991938 (6 June, 2017)

Trawöger, L. (2014). Convinced, ambivalent or annoyed: Tyrolean ski tourism stakeholders and their perceptions of climate change. Tourism Management, 40, 338-351.

UNWTO (2015). Tourism Highlights. 2015 Edition. United Nations World Tourism Organisation. Retrieved from http://www.eunwto.org/doi/pdf/10.18111/9789284416899 (6 June, 2017) 
Table 1. National climate and tourism policy documents.

\begin{tabular}{|c|c|c|c|c|c|c|c|}
\hline Country & $\begin{array}{l}\text { Policy } \\
\text { docu } \\
\text { ment } \\
\text { type }\end{array}$ & $\begin{array}{l}\text { Touri } \\
\text { sm } \\
\text { menti } \\
\text { oned }\end{array}$ & $\begin{array}{l}\text { Adapt } \\
\text { ation } \\
\text { mentio } \\
\text { ned }\end{array}$ & $\begin{array}{l}\text { Climat } \\
\text { e } \\
\text { change } \\
\text { mentio } \\
\text { ned }\end{array}$ & $\begin{array}{l}\text { Notification } \\
\mathrm{s}\end{array}$ & Year & Publisher \\
\hline \multicolumn{8}{|l|}{ Denmark } \\
\hline $\begin{array}{l}\text { Danish } \\
\text { Strategy for } \\
\text { Adaptation to } \\
\text { a Changing } \\
\text { Climate } \\
\end{array}$ & $\begin{array}{l}\text { Clima } \\
\text { te } \\
\text { strate } \\
\text { gy }\end{array}$ & no & & & & 2008 & $\begin{array}{l}\text { The Danish } \\
\text { Governme } \\
\text { nt }\end{array}$ \\
\hline $\begin{array}{l}\text { Denmark's } \\
\text { Fifth National } \\
\text { Communicatio } \\
\text { n on Climate } \\
\text { Change }\end{array}$ & $\begin{array}{l}\text { Clima } \\
\text { te } \\
\text { strate } \\
\text { gy }\end{array}$ & yes & & & $\begin{array}{l}\text { Contains a } \\
\text { section on } \\
\text { cruise ship } \\
\text { tourism. } \\
\text { Mentions the } \\
\text { impact of } \\
\text { melting sea } \\
\text { ice on } \\
\text { shipping } \\
\text { routes } \\
\text { (Greenland) }\end{array}$ & 2009 & $\begin{array}{l}\text { The } \\
\text { Ministry of } \\
\text { Climate } \\
\text { and Energy }\end{array}$ \\
\hline $\begin{array}{l}\text { The Danish } \\
\text { Climate Policy } \\
\text { Plan }\end{array}$ & $\begin{array}{l}\text { Clima } \\
\text { te } \\
\text { strate } \\
\text { gy }\end{array}$ & no & & & & 2013 & $\begin{array}{l}\text { The Danish } \\
\text { Governme } \\
\text { nt }\end{array}$ \\
\hline $\begin{array}{l}\text { Denmark at } \\
\text { Work - Plan } \\
\text { for Growth in } \\
\text { Danish } \\
\text { Tourism } \\
\text { (Summary) }\end{array}$ & $\begin{array}{l}\text { Touris } \\
\text { m } \\
\text { strate } \\
\text { gy }\end{array}$ & & no & no & & 2014 & $\begin{array}{l}\text { The Danish } \\
\text { Governme } \\
\text { nt }\end{array}$ \\
\hline $\begin{array}{l}\text { Tourism } \\
\text { Industry Sub- } \\
\text { Sectors,Countr } \\
\text { y Report } \\
\text { Denmark }\end{array}$ & $\begin{array}{l}\text { Touris } \\
\mathrm{m} \\
\text { strate } \\
\text { gy }\end{array}$ & & no & no & & 2014 & $\begin{array}{l}\text { European } \\
\text { Commissio } \\
\mathrm{n}\end{array}$ \\
\hline \multicolumn{8}{|l|}{ Finland } \\
\hline $\begin{array}{l}\text { National } \\
\text { Adaptation } \\
\text { Strategy of } \\
\text { Finland * }\end{array}$ & $\begin{array}{l}\text { Clima } \\
\text { te } \\
\text { strate } \\
\text { gy }\end{array}$ & yes & & & & 2005 & $\begin{array}{l}\text { Ministry of } \\
\text { Agriculture } \\
\text { and } \\
\text { Forestry }\end{array}$ \\
\hline $\begin{array}{l}\text { Finland's } \\
\text { National } \\
\text { Climate } \\
\text { Change } \\
\text { Adaptation } \\
\text { Plan } 2022 .\end{array}$ & $\begin{array}{l}\text { Clima } \\
\text { te } \\
\text { strate } \\
\text { gy }\end{array}$ & yes & & & & 2014 & $\begin{array}{l}\text { Ministry of } \\
\text { Agriculture } \\
\text { and } \\
\text { Forestry }\end{array}$ \\
\hline
\end{tabular}




\begin{tabular}{|c|c|c|c|c|c|c|c|}
\hline $\begin{array}{l}\text { Government } \\
\text { Resolution } 20 \\
\text { November } \\
2014\end{array}$ & & & & & & & \\
\hline $\begin{array}{l}\text { Finland's Fifth } \\
\text { National } \\
\text { Communicatio } \\
\text { n on Climate } \\
\text { Change }\end{array}$ & $\begin{array}{l}\text { Clima } \\
\text { te } \\
\text { strate } \\
\text { gy }\end{array}$ & yes & & & & 2009 & $\begin{array}{l}\text { Ministry of } \\
\text { the } \\
\text { Environme } \\
\text { nt \& } \\
\text { Statistics } \\
\text { Finland }\end{array}$ \\
\hline $\begin{array}{l}\text { National } \\
\text { Energy and } \\
\text { Climate } \\
\text { Strategy. } \\
\text { Government } \\
\text { Report to } \\
\text { Parliament on } \\
20 \text { March } \\
2013\end{array}$ & $\begin{array}{l}\text { Clima } \\
\text { te } \\
\text { strate } \\
\text { gy }\end{array}$ & no & & & & 2013 & $\begin{array}{l}\text { The } \\
\text { Governme } \\
\text { nt of } \\
\text { Finland }\end{array}$ \\
\hline $\begin{array}{l}\text { Valtioneuvost } \\
\text { on } \\
\text { periaatepäätös } \\
\text { Suomen } \\
\text { matkailupolitii } \\
\text { kasta** }\end{array}$ & $\begin{array}{l}\text { Touris } \\
\text { m } \\
\text { strate } \\
\text { gy }\end{array}$ & & no & yes & $\begin{array}{l}\text { Mentions } \\
\text { energy use } \\
\text { and climate } \\
\text { change } \\
\text { threat }\end{array}$ & 2011 & $\begin{array}{l}\text { Ministry of } \\
\text { Employme } \\
\text { nt and the } \\
\text { Economy }\end{array}$ \\
\hline $\begin{array}{l}\text { Finland's } \\
\text { Tourism } \\
\text { Strategy to } \\
2020\end{array}$ & $\begin{array}{l}\text { Touris } \\
\text { m } \\
\text { strate } \\
\text { gy }\end{array}$ & & no & yes & $\begin{array}{l}\text { Mentions } \\
\text { energy use } \\
\text { and climate } \\
\text { change } \\
\text { threat, and } \\
\text { adoption of } \\
\text { new } \\
\text { technologies }\end{array}$ & 2010 & $\begin{array}{l}\text { Ministry of } \\
\text { Employme } \\
\text { nt and the } \\
\text { Economy }\end{array}$ \\
\hline $\begin{array}{l}\text { Tourism } \\
\text { Industry Sub- } \\
\text { Sectors, } \\
\text { Country } \\
\text { Report Finland }\end{array}$ & $\begin{array}{l}\text { Touris } \\
\text { m } \\
\text { strate } \\
\text { gy }\end{array}$ & & no & yes & $\begin{array}{l}\text { Only coastal } \\
\text { tourism's } \\
\text { seasonality } \\
\text { to climate } \\
\text { mentioned }\end{array}$ & 2014 & $\begin{array}{l}\text { European } \\
\text { Commissio } \\
\mathrm{n}\end{array}$ \\
\hline \multicolumn{8}{|l|}{ Iceland } \\
\hline $\begin{array}{l}\text { Iceland's } \\
\text { Climate } \\
\text { Change } \\
\text { Strategy }\end{array}$ & $\begin{array}{l}\text { Clima } \\
\text { te } \\
\text { strate } \\
\text { gy }\end{array}$ & no & & & $\begin{array}{l}\text { Only } \\
\text { mentions } \\
\text { that } \\
\text { measures } \\
\text { related to } \\
\text { transport are } \\
\text { the } \\
\text { responsibilit } \\
\text { y of the } \\
\text { Ministry of } \\
\text { Transport, }\end{array}$ & 2007 & $\begin{array}{l}\text { Ministry } \\
\text { for the } \\
\text { Environme } \\
\text { nt }\end{array}$ \\
\hline
\end{tabular}




\begin{tabular}{|c|c|c|c|c|c|c|c|}
\hline & & & & & $\begin{array}{l}\text { Tourism and } \\
\text { Telecommun } \\
\text { ications }\end{array}$ & & \\
\hline $\begin{array}{l}\text { Iceland's Fifth } \\
\text { National } \\
\text { Communicatio } \\
\text { n on Climate } \\
\text { Change }\end{array}$ & $\begin{array}{l}\text { Clima } \\
\text { te } \\
\text { strate } \\
\text { gy }\end{array}$ & no & & & $\begin{array}{l}\text { Only } \\
\text { mentions } \\
\text { that the } \\
\text { tourism } \\
\text { industry } \\
\text { relies on } \\
\text { nature and } \\
\text { natural } \\
\text { beauty } \\
\end{array}$ & 2010 & $\begin{array}{l}\text { Ministry } \\
\text { for the } \\
\text { Environme } \\
\text { nt }\end{array}$ \\
\hline $\begin{array}{l}\text { Promote } \\
\text { Iceland: Long- } \\
\text { term Strategy } \\
\text { for the } \\
\text { Icelandic } \\
\text { Tourism } \\
\text { Industry }\end{array}$ & $\begin{array}{l}\text { Touris } \\
\text { m } \\
\text { strate } \\
\text { gy }\end{array}$ & & no & yes & & 2013 & $\begin{array}{l}\text { PKF } \\
\text { Accountant } \\
\text { s \& } \\
\text { Business } \\
\text { Advisers }\end{array}$ \\
\hline $\begin{array}{l}\text { Tourism } \\
\text { Industry Sub- } \\
\text { sectors, } \\
\text { Country } \\
\text { Report Iceland } \\
\end{array}$ & $\begin{array}{l}\text { Touris } \\
\text { m } \\
\text { strate } \\
\text { gy }\end{array}$ & & no & no & & 2014 & $\begin{array}{l}\text { European } \\
\text { Commissio } \\
\mathrm{n}\end{array}$ \\
\hline \multicolumn{8}{|l|}{ Norway } \\
\hline $\begin{array}{l}\text { Climate } \\
\text { change } \\
\text { adaptation in } \\
\text { Norway - } \\
\text { Meld. St. } 33 \\
\text { (2012-2013) } \\
\text { Report to the } \\
\text { Storting (white } \\
\text { paper) }\end{array}$ & $\begin{array}{l}\text { Clima } \\
\text { te } \\
\text { strate } \\
\text { gy }\end{array}$ & yes & & & $\begin{array}{l}\text { Tourism and } \\
\text { sustainable } \\
\text { tourism } \\
\text { mentioned in } \\
\text { several } \\
\text { occasions }\end{array}$ & 2013 & $\begin{array}{l}\text { Norwegian } \\
\text { Ministry of } \\
\text { Climate } \\
\text { and } \\
\text { Environme } \\
\text { nt }\end{array}$ \\
\hline $\begin{array}{l}\text { Norway’s } \\
\text { Fifth National } \\
\text { Communicatio } \\
\text { n on Climate } \\
\text { Change }\end{array}$ & $\begin{array}{l}\text { Clima } \\
\text { te } \\
\text { strate } \\
\text { gy }\end{array}$ & yes & & & & 2009 & $\begin{array}{l}\text { Norwegian } \\
\text { Ministry of } \\
\text { the } \\
\text { Environme } \\
\text { nt }\end{array}$ \\
\hline $\begin{array}{l}\text { Regjeringens } \\
\text { strategi for de } \\
\text { internasjonale } \\
\text { klimaforhandli } \\
\text { ngene** }\end{array}$ & $\begin{array}{l}\text { Clima } \\
\text { te } \\
\text { strate } \\
\text { gy }\end{array}$ & no & & & & 2013 & $\begin{array}{l}\text { Norwegian } \\
\text { Ministry of } \\
\text { Climate } \\
\text { and } \\
\text { Environme } \\
\text { nt }\end{array}$ \\
\hline $\begin{array}{l}\text { Tourism } \\
\text { Strategy 2014- } \\
2020\end{array}$ & $\begin{array}{l}\text { Touris } \\
\text { m } \\
\text { strate } \\
\text { gy }\end{array}$ & & no & no & & 2014 & $\begin{array}{l}\text { Innovation } \\
\text { Norway }\end{array}$ \\
\hline
\end{tabular}




\begin{tabular}{|c|c|c|c|c|c|c|}
\hline $\begin{array}{l}\text { The } \\
\text { Government's } \\
\text { Tourism } \\
\text { Strategy, } \\
\text { Destination } \\
\text { Norway, } \\
\text { National } \\
\text { Strategy for } \\
\text { the Tourism } \\
\text { Industry }\end{array}$ & $\begin{array}{l}\text { Touris } \\
\text { m } \\
\text { strate } \\
\text { gy }\end{array}$ & & no & yes & 2012 & $\begin{array}{l}\text { Norwegian } \\
\text { Ministry of } \\
\text { Trade and } \\
\text { Industry }\end{array}$ \\
\hline $\begin{array}{l}\text { Tourism } \\
\text { Industry Sub- } \\
\text { Sectors, } \\
\text { Country } \\
\text { Report } \\
\text { Norway } \\
\end{array}$ & $\begin{array}{l}\text { Touris } \\
\text { m } \\
\text { strate } \\
\text { gy }\end{array}$ & & no & no & 2014 & $\begin{array}{l}\text { European } \\
\text { Commissio } \\
n\end{array}$ \\
\hline \multicolumn{7}{|l|}{ Sweden } \\
\hline $\begin{array}{l}\text { Sweden } \\
\text { Facing } \\
\text { Climate } \\
\text { Change - } \\
\text { Threats and } \\
\text { Opportunities* }\end{array}$ & $\begin{array}{l}\text { Clima } \\
\text { te } \\
\text { strate } \\
\text { gy }\end{array}$ & yes & & & 2007 & $\begin{array}{l}\text { Swedish } \\
\text { Governme } \\
\text { nt Official } \\
\text { Reports }\end{array}$ \\
\hline $\begin{array}{l}\text { Sweden's Fifth } \\
\text { National } \\
\text { Communicatio } \\
\text { n on Climate } \\
\text { Change * }\end{array}$ & $\begin{array}{l}\text { Clima } \\
\text { te } \\
\text { strate } \\
\text { gy }\end{array}$ & yes & & & 2009 & $\begin{array}{l}\text { Ministry of } \\
\text { the } \\
\text { Environme } \\
\text { nt }\end{array}$ \\
\hline $\begin{array}{l}\text { Sveriges } \\
\text { klimastrategi* } \\
*\end{array}$ & $\begin{array}{l}\text { Clima } \\
\text { te } \\
\text { strate } \\
\text { gy }\end{array}$ & no & yes & & 2001 & $\begin{array}{l}\text { Ministry of } \\
\text { the } \\
\text { Environme } \\
\text { nt }\end{array}$ \\
\hline $\begin{array}{l}\text { Tourism } \\
\text { Industry Sub- } \\
\text { Sectors, } \\
\text { Country } \\
\text { Report } \\
\text { Sweden } \\
\end{array}$ & $\begin{array}{l}\text { Touris } \\
\text { m } \\
\text { strate } \\
\text { gy }\end{array}$ & & no & no & 2014 & $\begin{array}{l}\text { European } \\
\text { Commissio } \\
\mathrm{n}\end{array}$ \\
\hline $\begin{array}{l}\text { National } \\
\text { strategi för } \\
\text { Svensk } \\
\text { besöksnäring* } \\
\text { * }\end{array}$ & $\begin{array}{l}\text { Touris } \\
\text { m } \\
\text { strate } \\
\text { gy }\end{array}$ & & no & yes & 2010 & $\begin{array}{l}\text { Svensk } \\
\text { Turism } \\
\text { AB/ } \\
\text { Decennium } \\
\text { AB }\end{array}$ \\
\hline
\end{tabular}

* Includes a specific section on tourism, ** Document not available in English 